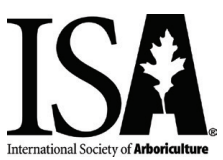

Arboriculture \& Urban Forestry 2018. 44(2):59-72

\title{
Why Count Trees? Volunteer Motivations and Experiences with Tree Monitoring in New York City
}

\author{
Michelle L. Johnson, Lindsay K. Campbell, Erika S. Svendsen, \\ and Philip Silva
}

\begin{abstract}
Volunteer programs can benefit from a deeper understanding of the motivations and experiences of people engaged in citizen science. Research to date has studied motivations of citizen scientists and tree-planting volunteers. Less work has focused on tree-monitoring volunteers, a role that is rapidly increasing as more cities involve the public in monitoring the urban forest. Researchers conducted an assessment of volunteers $(n=636$ respondents $)$ of the TreesCount! 2015 street tree census in New York City, New York, U.S., to understand volunteers' demographics, motivations, experiences, and levels of civic engagement. Semistructured interviews $(n=40)$ were also conducted on a subset of the initial assessment respondents, to deepen understanding of these factors. Like tree-planting volunteers in previous studies, volunteers were more likely to be highly educated, female, white, and with high income levels. Top self-identified motivations for participation included personal values, wanting to contribute, and a desire for education or learning. Demographics correlated with different motivations, suggesting opportunities for targeting recruitment efforts to better reach underrepresented populations. Researchers also found motivations shifted slightly in post-census interviews, also identifying a new theme of exploring the city. Street-tree monitoring presents opportunities for contributing to one's community or city, and for learning about trees and urban nature, suggesting these acts of engagement can both strengthen connections to social-ecological systems and provide personal benefits. At the same time, considering volunteer motivations, experiences, and outcomes when designing programs can positively affect participation turnout, effort, and retention.

Key Words. Citizen Science; Civic Engagement; New York City; Stewardship; Tree Monitoring; Urban Forest.
\end{abstract}

Citizen science programs engage the public in scientific endeavors and are an increasingly popular approach to producing scientific knowledge. Jordan et al. (2012) defines citizen science as "partnerships between those involved with science and the public in which authentic data are collected, shared, and analyzed." With advancements in technology, it has become easier for people to participate in data collection, analysis, and interpretation for projects occurring in their own communities. Citizen science programs are often organized by academic institutions and non-profit organizations, but government agencies have begun taking notice and integrating the public into data collection and analysis. Engaging community members in science can also help strengthen management of natural resources, through linking monitoring, research, and policy making (Kofinas 2009). Citizen scientists themselves can benefit through increased subject knowledge and scientific skills, as well as an increase in self-efficacy related to addressing environmental issues (Merenlender et al. 2016).

City-level tree-monitoring programs have begun engaging the public in monitoring efforts (Vogt and Fischer 2014), yet these programs are understudied with regards to volunteer motivations and demographics. Previous research on tree monitoring has focused on biophysical data collected through tree inventories and censuses to understand the health, growth, and longevity of the urban forest (Lu et al. 2010; Roman et al. 2013). Such municipally-led projects fall into Miller-Rushing et al.'s (2012) category of contributory citizen science, and they may or may not involve processing and analyzing data to 
answer a research question. Through research on other citizen science projects, there are important social outcomes and implications of engagement with tree monitoring, most notably for the volunteer participants themselves (Wright et al. 2015). Effective data collection and monitoring can also contribute to stewardship outcomes by enabling stewards, managers, and researchers to track the effects of their efforts. Monitoring is an important aspect of stewardship, in addition to conserving, managing, advocating for, and educating people about the local environment (Svendsen and Campbell 2008; Fisher et al. 2012).

This paper focuses on understanding treemonitoring volunteer demographics, participation motivations, experiences, and interactions between these factors. Previous research on volunteer tree planters in New York City has increased understanding of the relationship between urban greening and civic participation, pointing to tree planting as an on-ramp to other forms of civic engagement (Fisher et al. 2015). Does this relationship extend to monitoring efforts by citizen scientists, and if so, how? It is also important to understand whether and how members of the public are mobilized to engage with tree-monitoring efforts, as these campaigns and practices continue to proliferate across cities and towns. Researching participation motivations is essential for understanding, recruiting, and retaining participants in citizen-science activities (Wright et al. 2015; Merenlender et al. 2016), as well as stewardship activities (Fisher et al. 2015). Finally, understanding whether motivations vary by demographics is critical to ensuring recruitment efforts are effective and inclusive in appealing to multiple publics.

\section{Volunteer Motivations for Environ- mental Engagement and Citizen Science}

Volunteering, like any activity, can be motivated by both intrinsic and extrinsic factors. Intrinsic motivation refers to being motivated by enjoyment of the behavior, while extrinsic motivation can be influenced by internal and/or external factors, to avoid negative consequences, or achieve positive consequences (Ryan and Deci 2000). Motivations are often studied because of their links to direct, observable behaviors. According to the functional approach in psychology, different individuals may participate in the same activity with different needs, goals, and purposes (Clary et al. 1998). Six functions identified for volunteering in Clary et al.'s (1996) Volunteer Function Index (VFI) are: understanding, social, values, protective (e.g., volunteering as a means of coping with internal conflicts, stresses, or guilt), career, and enhancement. The VFI has been applied to later research studies focused on environmental volunteering, which have identified additional functions (Bruyere and Rappe 2007; Bramston et al. 2011; Wright et al. 2015).

A number of studies examining motivations of urban forestry volunteers and citizen scientists have noted variations of the functions identified in Clary et al. (1996). Motivations reported by Chicago TreeKeepers included emotional, aesthetic, or spiritual values (Westphal 1993). Desire to improve one's neighborhood, desire for education, and social interaction were the three most important factors motivating urban forest volunteers in New York City, New York, and Philadelphia, Pennsylvania, U.S. (Still and Gerhold 1997). Tree-planting stewards in NYC's MillionTreesNYC program predominantly stayed involved because of their care for their city and for their personal connections with other people in the city (Fisher et al. 2015). A separate study examining NYC's MillionTreesNYC program identified varied motivations, including environmental benefits of trees, community service, benefits to youth, enjoyment from planting trees, the need for more trees, and attending the event as part of a school class (Moskell et al. 2010). Most highly rated motivations from volunteer tree planters in Detroit, Michigan, U.S., included working with nature, helping their neighborhood, creating something, giving back to their communities, getting to know people in neighborhoods, and good exercise (Austin 2002). Through a factor analysis of survey responses, Grese et al. (2000) identified four types of benefits to urban forestry volunteering: helping the environment, exploration, spirituality, and, finally, personal and social benefits. These studies identify a wide variety of motivating factors for urban forestry volunteers, relating to both personal and community-level benefits. 
Studies of citizen-scientist motivations have identified similar motivations. Avian research volunteers were motivated by (in order of importance): recreation or nature-based values, personal values, personal growth, social interactions, and project organization (Wright et al. 2015). Motivations for participation in UK citizen-science programs included altruistic, personal development, personal, to share knowledge, someone else wanted me to do it, and other/don't know/ can't remember (Geohegan et al. 2016). Bell et al. (2008) identified another motivation type, whereby volunteers were motivated by wanting to share their knowledge with others. From these studies, citizen scientists have often identified knowledge or sharing knowledge as a common motivating factor, but this factor was not always identified in studies of urban forestry volunteers.

Motivations to initiate an activity are not always the same as those that inspire continued participation. Initial motivation has often been the research focus, but a few studies have also looked at continued engagement. In a study of stewardship volunteers, helping the environment and learning were important initial motivations, while social factors and project organization significantly predicted volunteer commitment (Ryan et al. 2001). Asah and Blahna (2013) found similar results, where volunteer commitment to urban conservation was motivated by personal, social, and community functions to a greater extent than environmental motivations. In their study, the environment was a significant motivator only when volunteering met these other goals. Frequency of volunteering is motivated more by personal and social benefits rather than by environmentrelated reasons (Asah and Blahna 2012). Similar results were found in a study of volunteer satisfaction; initial motivations for volunteering included value-driven motivations, but over time there was a stronger correlation between self-related motivations and the amount of volunteers' contributions (Finkelstein 2008). This suggests that understanding the motivation factors of participants can assist with volunteer-retention efforts.

Participation and motivation also can be affected by program structure. Motivations of volunteers in previous studies have included project organization (which can refer to a well- organized project), clear expectations, and working with a good leader (Ryan et al. 2001; Bruyere and Rappe 2007). Volunteer experience has implications for future volunteers; satisfied volunteers likely will communicate positively to others about the program, contributing to recruitment and social capital (Wright et al. 2015). Conversely, in some contexts, formalized reward structures can act as a disincentive for continued levels of volunteering, by undermining intrinsic motivation (Lepper et al. 1973; Deci and Ryan 1985). In general, intrinsic motivation is more important to outcomes when incentives are not directly tied to outcomes, and less so when incentives are tied to outcomes (Cerasoli et al. 2014). However, this "crowding out" effect is subjectdependent; health behaviors are not moderated by the same factors as observed in psychology and economic studies (Promberger and Marteau 2013).

\section{Volunteer Demographics}

Volunteerism is affected by individual characteristics and social structure. In the United States, social characteristics like education level, income, gender, and race can affect who engages in volunteer activities. Overall, volunteers tend to be composed of more women than men, although women and men also volunteer in different domains. One study found that white Americans are more likely to volunteer than African Americans, even after controlling for social class, and Hispanic Americans and Asian Americans are the least likely to volunteer (Foster-Bey 2008). Differences in the racial composition of volunteers are supported by other research (Rotolo et al. 2010; Taniguchi 2012); but it is also likely that volunteer data from minority groups are underreported (Boyle and Sawyer 2010). Age and available time are also other factors affecting volunteer rates (Wilson 2012). In a study of tree-planting volunteers in New York City, Fisher et al. (2015) found tree-planting individuals to be more politically liberal, have higher levels of educational attainment, be slightly more female than male, and to be more white, although they note differences may be due more to the intersection of class with race and ethnicity. A study of tree inventory volunteers in NYC found volunteers were predominately white, middle-aged, well-educated, and with middle-class 
incomes (Still and Gerhold 1997), which aligns with Fisher et al.s (2015) tree-planter demographics.

This paper presents the results of an assessment of participants of New York City's TreeCount! 2015 (TC2015) tree census initiative, which occurred in 2015 and 2016, along with followup interviews, to examine motivations as they relate to experience and volunteer demographics. Structurally, the level of importance and types of motivations are known to vary by education, income, race, and gender (Musick and Wilson 2007). However, little work to date has focused on examining the intersection of volunteer motivations and demographics, particularly for environmental or citizen science volunteers, necessitating further research on this topic.

\section{MATERIALS AND METHODS}

\section{Background}

The City of New York Department of Parks and Recreation (NYC Parks) conducts a census of all street trees in NYC every ten years (i.e., trees planted in the public right-of-way alongside streets, outside of parks), an effort that commenced with the 1995/1996 census. Each census takes approximately two years to complete and involves the collection of spatial and morphological data for every street tree in NYC, and data about the condition of their planting spaces. TC2015 was designed for greater volunteer involvement than the previous two censuses, with a larger recruitment and training effort and a more sophisticated data-collection interface designed specifically for volunteers. Volunteer recruitment was conducted through city-wide advertisements, newspaper advertisements, word of mouth, and engagement of city-based partner groups. Volunteers signed up on the TC2015 website and completed online training, after which they attended in-person training on data-collection methodology. Training focused on how to navigate the TC2015 web app (and tablet) to be used for data collection, collect accurate spatial data, properly measure a tree, identify different tree species, and collect data for several other variables. After training, volunteers participated in data-collection events, which were scheduled and run by NYC Parks staff or partner groups. Volunteers who exhibited a higher level of commitment over time could also collect data on their own, once NYC Parks determined they attained a high level of skill. Volunteers collected data on $34 \%$ of all street trees citywide, which amounted to over 225,000 trees.

\section{Data Collection}

In collaboration with NYC Parks, an assessment was administered to all TC2015 volunteers who attended training, signed up for events, and were not NYC Parks employees or close affiliates. Registered volunteers with the TC2015 census signed up for accounts using an email address, and those who signed up for events were included in the sampling frame. From this list of participating individuals $(\mathrm{n}=2,438)$, an email was sent with an invitation letter and anonymous link to an online assessment through SurveyMonkey ${ }^{\oplus}$. Researchers then sent up to four reminders to individuals to complete the assessment. The assessment opened in 11 May 2015, and was closed on 01 January 2016. Researchers received 661 responses to the assessment, for a response rate of $27.2 \%$. Individuals under 18 were excluded, for a total sample of 636 .

The protocol for this assessment was developed based upon previous tree census assessments and research findings from Fisher et al. (2015). The assessment contains 34 questions, including yes/no, multiple choice, and open-ended questions (Supplementary Materials 1). Questions focused on how volunteers first heard about TC2015, event experiences, neighborhood perceptions, civic engagement, political views, and demographics. The assessment took approximately 10 minutes to complete.

A subset of assessment respondents $(\mathrm{n}=241)$ identified a willingness to participate in a followup interview. From this subset, each individual was assigned to one of four categories based on whether they had a college degree (yes/no) and prior experience volunteering with NYC Parks (yes/no). From these categories, individuals were randomly selected for follow-up interviews by phone. Forty individuals were interviewed, and there were three refusals. Following the receipt of informed consent via email (Rutgers University IRB\#E17-086), interviews were conducted confidentially, using a semistructured format (Supplementary Materials 2). Interviews were held from October 2016 to January 2017, after the conclusion of TC2015. They lasted approximately 30 minutes and were audio recorded 
and fully transcribed. This paper makes use of open-ended questions addressing recruitment and motivations, but the interviews also addressed topics of learning outcomes and civic engagement. For each respondent, researchers also identified the number of city blocks inventoried by each individual, which was recorded in the TC2015 app.

\section{Data Analysis}

\section{Assessment}

Assessment responses were downloaded from SurveyMonkey into Microsoft ${ }^{\oplus}$ Excel $^{\mathrm{TN}}$ and examined for missing data. Responses to multiple-choice questions were presented in a summary format, and where applicable, included in statistical analyses. Organization names identified by respondents in open-ended questions were standardized. All statistical analyses were conducted in R 3.2.3 (R Core Team 2017). Researchers compared early and late responders to the assessment to check for nonresponse bias, using t-tests for continuous data and $\chi^{2}$ tests for categorical data (Groves 2006).

In Excel, researchers qualitatively analyzed open-ended responses to the question, "Why did you decide to participate in TreesCount! 2015?" (Q10, SM1). Responses to questions were coded separately by two different researchers via an open coding scheme that identified key phrases and concepts (Lofland et al. 2005). These initial codes were compared and discussed, and discrepancies were examined using an iterative approach until consensus was reached among the coders, thereby enhancing reliability (Neuman 2003). Thematic clusters were then created to aggregate common codes together into broader themes, but specific subcategories were also retained. The thematic clusters emerged out of key phrases, repeated language, and common ideas (Ryan and Bernard 2003).

Researchers then assigned themes as present or absent for each respondent. Also included was each motivation theme as the dependent variable in logistic regressions with a set of demographic variables as the independent variables (Table 1). Logistic regressions were conducted using the glm package for R (R Core Team 2017). Nagelkerke pseudo- $R^{2}$ were calculated for each regression, using the pscl package for $\mathrm{R}$, and also calculated goodness-of-fit $\chi^{2}$ tests comparing the full regression model to an interceptonly model, using the lmtest package for $\mathrm{R}$.

\section{Interviews}

Interview transcripts were analyzed using NVivo Pro 11 (QSR International Pty Ltd. 2015). Qualitative coding of the semi-structured interviews focused on volunteer motivations to participate in tree-counting activities (Q2, SM2). Researchers began with the initial set of thematic codes that were identified through coding the assessment data (see Table 2), and also identified new themes that emerged from the more in-depth interview data (Strauss and Corbin 1990; Charmaz 2001). Finally, researchers combined assessment and interview results for individuals participating in both and associated those results with the NYC Parks TC2015 database, which includes information on mapping amount and location by participant.

Table 1. Variables derived from the assessment and included in statistical analysis.

\begin{tabular}{ll}
\hline Variable & Format \\
\hline Motivations & Themes coded from open-ended questions, recoded as factor variable $(1=$ motivation mentioned, $0=$ motivation not mentioned). \\
Gender (female) & Multiple choice (female, male, other), other responses dropped from analysis, recoded as a factor variable (female $=1$, male $=0)$. \\
Political views & Likert scale $1=$ very liberal, $7=$ very conservative, continuous. \\
Race (white) & Multiple choice, recoded as a factor variable (white/Caucasian $=1$, other categories $=0)$. \\
Age & Continuous number. \\
Education & Multiple choice, recoded as a factor variable (bachelor's degree or higher $=1$, other levels of education $=0)$. \\
Income & Multiple choice. \\
$\begin{array}{l}\text { Proportion of life } \\
\text { in NYC }\end{array}$ & Derived from years of life in NYC divided by age, continuous.
\end{tabular}


Table 2. Demographics of TC2015 assessment respondents as compared to New York City.

\begin{tabular}{|c|c|c|}
\hline People & Respondents (\%) & New York City ${ }^{z}(\%)$ \\
\hline \multicolumn{3}{|l|}{ Gender } \\
\hline Female persons & 63.3 & 52.5 \\
\hline Male persons & 36.7 & 47.5 \\
\hline Other & 0.01 & $\mathrm{n} / \mathrm{a}$ \\
\hline \multicolumn{3}{|l|}{ Race and Hispanic Origin } \\
\hline White & 69.4 & 44 \\
\hline Black or African American & 15.2 & 25.5 \\
\hline American Indian and Alaska Native & 0.8 & 0.7 \\
\hline Asian alone & 7.7 & 12.7 \\
\hline Native Hawaiian and Other Pacific Islander & $\mathrm{n} / \mathrm{a}$ & 0.1 \\
\hline Two or more races & $\mathrm{n} / \mathrm{a}$ & 4 \\
\hline Hispanic or Latino & 6.9 & 28.6 \\
\hline \multicolumn{3}{|l|}{ Education } \\
\hline High school graduate or higher, percent of persons age 25 years,$+ 2010-2014$ & 99.6 & 80.1 \\
\hline Bachelor's degree or higher, percent of persons age 25 years+, 2010-2014 & 86.8 & 35 \\
\hline
\end{tabular}

${ }^{2}$ New York City demographic data from 2010 Census.

\section{RESULTS}

\section{Response Bias Checks}

To check for non-response bias, early responders were identified as those responding during the first two months of the six-month assessment window ( $\mathrm{n}=103)$, and late responders as those responding during the last two months $(\mathrm{n}=91)$. No significant differences were found between early and late responders in terms of race, income, education, years in neighborhood, or years in New York City. Researchers did find differences in respondents' gender $(P<0.01)$ and age $(P<0.05)$. The ratio between men and women was higher for early responders, as more men responded earlier rather than later. Researchers also found that early responders were more likely to be older than late responders. As late responders are similar to nonrespondents, this suggests that the sample may underrepresent men and younger individuals, but that for other demographic variables, like race, income, education, and time in the region, the sample represents the TC2015 volunteer population.

\section{Volunteer Characteristics}

The demographic composition of assessment respondents was analyzed by age, race, education, and income level. Respondents' ages ranged from 18 to 83 (mean $=44$, s.d. $=16.58$ ). The majority of respondents were well-educated, having completed university and/or received a graduate degree (Table 2), had higher rather than lower income, and were employed broadly across sectors. In com- parison to New York City, respondents tended to be more female, white, and have more years of formal education. Politically, $42.8 \%$ of respondents identified as liberal, while $11.2 \%$ identified as middle of the road, and $2.9 \%$ as conservative.

Researchers also examined volunteers' residential tenure at the neighborhood and city levels, whether they came alone or as part of a group, and whether they had prior stewardship experience. Respondents had lived in their neighborhood from two weeks to 66 years (median $=$ five years, s.d. = 13.26), averaging 10.8 years in their neighborhood. Respondents had lived in the NYC area from two weeks to 79 years $($ median $=22$ years, s.d. $=19.84$ ), averaging 24 years. Participating individuals that came to organized TC2015 events predominantly attended these events alone (59.3\%), although some attended with a partner $(10.5 \%)$, friends and neighbors $(10.1 \%)$, colleagues $(8.7 \%)$, family (6.3\%), and/or members of an organization (5.1\%). Over half of respondents (53.2\%) identified themselves as having taken care of trees before, in one or more of the following: their yard $(32.2 \%)$, on the street $(30.7 \%)$, or in a park $(13.6 \%)$. For most respondents, this was their first time volunteering with NYC Parks (59.6\%). However, many respondents had volunteered with other NYC Parks volunteer events, including MillionTreesNYC tree plantings (13.2\%), stewardship (13.2\%), and Care Captain workshops (street tree stewardship workshops, 3.6\%); It's My Park! Day events (13.3\%); Natural Areas events (forest stewardship, 6.4\%); and the 2005 (8.6\%) and 1995 (1.9\%) tree censuses. 


\section{Motivations and Demographics}

Individuals' motivations for volunteering are critical for understanding how to recruit and maintain a group of committed volunteers. Responses to an open-ended assessment question of "Why did you volunteer?" resulted in eight coded themes (Table 3). Out of the 636 respondents, 529 answered this question.

Logistic regressions associating individual motivation themes with demographic variables identified differences in motivation themes by demographics (Table 4; Table 5). For all regressions, the same was 459 , as not all respondents completed all questions pertinent to the regression analysis. One's political view (being more conservative) was associated with the Educate theme, with a log odds ratio of 1.32. Race (being white) was negatively associated with the Incentive theme, with a notable effect size (log odds ratio $=0.42$ ) and positively associated with the Values theme, with a log odds ratio of 1.38 . Income was positively associated with the Fun theme and negatively associated with the Past Experience theme, with a log odds ratio of 0.80 .
Proportion of life in NYC was negatively associated with the Contribute theme, with a notable effect size (log odds ratio $=0.24)$ and positively associated with the Past Experience theme, with a notable effect size (log odds ratio $=5.29$ ). Some themes, Outdoors and Social / Meet People, had no associated demographic variables; these models also had a lower pseudo- $\mathrm{R}^{2}$. Models that did not meet a goodness-of-fit test against an intercept model included Contribute, Fun, Outdoors, and Social models. Examining the Wald statistic results to identify individual-level significance (Table 5), researchers created alternate models for the Contribute and Fun themes. For the Contribute theme, a Proportion of Life in NYC-only model was a better fit than a null model $(9.10, P$ $=0.003$ ), with a relatively robust beta coefficient $(-1.40$, as compared to -1.41 in the full model) and a similar odds ratio to the full model. For the Fun theme, an income-only model was a better fit than a null model $\left(\chi^{2}=7.11, P=0.008\right)$, with a robust beta coefficient for income $(0.26)$ and a similar odds ratio (1.26) to the full model.

Table 3. Emergent coded themes on TC2015 volunteer motivations $(n=529)$.

\begin{tabular}{|c|c|c|c|c|}
\hline Codes & Definition & Example quote & Percent & Count \\
\hline Values & $\begin{array}{l}\text { Identifying something as } \\
\text { important }\end{array}$ & $\begin{array}{l}\text { "I think that the overall project for the } \\
\text { continued greening of NYC is very important." }\end{array}$ & $29.1 \%$ & 230 \\
\hline Contribute & $\begin{array}{l}\text { Making meaning in one's } \\
\text { life and the world around them }\end{array}$ & $\begin{array}{l}\text { "NYC has been caring for me, so I thought } \\
\text { I'd give a little something back." }\end{array}$ & $19.6 \%$ & 155 \\
\hline Educate / Learning & Wanted to learn something & $\begin{array}{l}\text { "I love identifying and learning about trees, } \\
\text { especially those in NYC. This event is a great } \\
\text { way to keep learning and help an important } \\
\text { effort at the same time." }\end{array}$ & $19.3 \%$ & 153 \\
\hline Incentive & $\begin{array}{l}\text { Had an incentive to } \\
\text { participate-extrinsic } \\
\text { motivation }\end{array}$ & $\begin{array}{l}\text { "To earn concert tickets and to learn more } \\
\text { about the tree census efforts of NYC and the } \\
\text { neighborhoods in which they were occurring"z }\end{array}$ & $11.9 \%$ & 94 \\
\hline Fun / Enjoyment & Sounded fun & $\begin{array}{l}\text { "A constructive/fun way to support the } \\
\text { NYC environment." }\end{array}$ & $9.7 \%$ & 77 \\
\hline Past Experience & $\begin{array}{l}\text { Already have volunteered, } \\
\text { already have experience }\end{array}$ & $\begin{array}{l}\text { "I was proud to do it in } 2005 \text { and wanted } \\
\text { to participate again." }\end{array}$ & $5.3 \%$ & 42 \\
\hline Outdoors & Wanted to be outdoors & $\begin{array}{l}\text { "I love being outside, and it seemed like a } \\
\text { great way to get some sunshine and exercise } \\
\text { while doing good!" }\end{array}$ & $2.8 \%$ & 22 \\
\hline Social / Meet People & $\begin{array}{l}\text { Meet new people, be } \\
\text { around people/family }\end{array}$ & $\begin{array}{l}\text { "Learning experience and to meet } \\
\text { someone new." }\end{array}$ & $2.3 \%$ & 18 \\
\hline Total & & & $100.0 \%$ & 791 \\
\hline
\end{tabular}

${ }^{7}$ Afropunk offered free concert tickets to individuals who registered and attended a TC2015 event hosted within their TreesCount! adopted area. 
Table 4. Logistic regression results (unstandardized coefficients and odds ratios) for each TC2015 motivation theme by demographic variables $(n=459)$.

\begin{tabular}{|c|c|c|c|c|c|c|c|c|c|c|c|c|c|c|c|c|}
\hline & \multicolumn{2}{|l|}{ Values } & \multicolumn{2}{|c|}{ Educate } & \multicolumn{2}{|c|}{ Contribute } & \multicolumn{2}{|l|}{ Fun } & \multicolumn{2}{|c|}{ Incentive } & \multicolumn{2}{|c|}{ Outdoors } & \multicolumn{2}{|c|}{ Past experience } & \multicolumn{2}{|c|}{ Social } \\
\hline & $\beta$ & Odds & $\beta$ & Odds & $\beta$ & Odds & $\beta$ & Odds & $\beta$ & Odds & $\beta$ & Odds & $\beta$ & Odds & $\beta$ & Odds \\
\hline Intercept & -0.86 & 0.42 & $-2.83^{z}$ & 0.06 & -1.48 & 0.23 & $-4.50^{\mathrm{z}}$ & 0.01 & -1.17 & 0.31 & $-4.44^{y}$ & 0.12 & $-4.69^{y}$ & 0.01 & -3.58 & 0.03 \\
\hline Gender (female) & -0.15 & 0.99 & 0.38 & 1.46 & 0.43 & 1.04 & 0.47 & 1.60 & -0.20 & 0.82 & 1.27 & 3.06 & 1.16 & 3.19 & 0.59 & 1.80 \\
\hline Political views & -0.01 & 0.99 & $0.28^{\mathrm{y}}$ & 1.32 & 0.15 & 1.16 & -0.35 & 0.71 & -0.12 & 0.89 & 0.57 & 1.78 & -0.23 & 0.80 & -0.47 & 0.63 \\
\hline Race (white) & 0.32 & 1.38 & 0.32 & 1.38 & 0.01 & 1.01 & 0.00 & 1.00 & $-0.86^{\mathrm{y}}$ & 0.42 & 0.77 & 2.17 & -0.14 & 0.87 & -0.01 & 0.99 \\
\hline Age & $0.03^{x}$ & 1.03 & -0.01 & 0.99 & 0.01 & 1.01 & 0.00 & 1.00 & -0.02 & 0.98 & -0.03 & 0.97 & 0.01 & 1.01 & 0.24 & 1.27 \\
\hline Education & -0.13 & 0.88 & 0.35 & 1.41 & -0.34 & 0.97 & 0.08 & 1.08 & 0.24 & 1.27 & -0.07 & 0.93 & 0.48 & 1.61 & -0.36 & 0.70 \\
\hline Income & -0.05 & 0.95 & -0.02 & 0.98 & 0.07 & 1.07 & $0.26^{y}$ & 1.30 & -0.03 & 0.97 & 0.06 & 1.06 & $-0.22^{y}$ & 0.80 & 0.27 & 1.31 \\
\hline $\begin{array}{l}\text { Proportion of } \\
\text { life in NYC }\end{array}$ & -0.21 & 0.81 & -0.83 & 0.44 & $-1.41^{z}$ & 0.24 & -0.01 & 0.99 & 0.95 & 2.59 & -1.80 & 0.17 & $1.67^{y}$ & 5.29 & 0.15 & 1.16 \\
\hline $\begin{array}{l}\text { Nagelkerke } \\
\text { pseudo- }{ }^{2}\end{array}$ & 0.61 & & 0.56 & & 0.54 & & 0.6 & & 0.58 & & 0.46 & & 0.55 & & 0.36 & \\
\hline $\begin{array}{l}\text { Goodness-of-fit } \\
\text { test against null } \\
\text { model }\left(\chi^{2}\right)\end{array}$ & $17.42^{y}$ & & $14.32^{\mathrm{y}}$ & & 12.58 & & 11.62 & & $16.09^{y}$ & & 11.98 & & $19.60^{z}$ & & 5.11 & \\
\hline $\mathrm{n}$ & 459 & & 459 & & 459 & & 459 & & 459 & & 459 & & 459 & & 459 & \\
\hline
\end{tabular}

Table 5. Wald test statistic for each TC2015 motivation theme logistic regression by demographic variables $(n=459)$.

\begin{tabular}{|c|c|c|c|c|c|c|c|c|}
\hline & Values & Educate & Contribute & Fun & Incentive & Outdoors & Past experience & Social \\
\hline Gender (female) & 0.00 & 1.69 & 0.25 & 1.36 & 0.34 & 2.45 & 3.22 & 0.71 \\
\hline Political views & 0.00 & $3.94^{\mathrm{z}}$ & 1.11 & 2.21 & 0.41 & 3.51 & 0.73 & 1.21 \\
\hline Race (white) & 1.17 & 0.92 & 0.00 & 0.00 & $5.79^{\mathrm{z}}$ & 0.84 & 0.07 & 0.08 \\
\hline Age & $12.42^{y}$ & 0.49 & 0.57 & 0.07 & 3.58 & 1.21 & 0.66 & 0.15 \\
\hline Education & 0.60 & 3.00 & 0.04 & 0.08 & 0.96 & 0.03 & 1.93 & 0.82 \\
\hline Income & 0.81 & 0.13 & 1.20 & $5.55^{\mathrm{z}}$ & 0.12 & 0.16 & $5.16^{z}$ & 2.22 \\
\hline $\begin{array}{l}\text { Proportion of } \\
\text { Life in NYC }\end{array}$ & 0.30 & 3.65 & $9.79^{y}$ & 0.00 & $3.84^{\mathrm{z}}$ & 2.65 & $5.27^{z}$ & 0.02 \\
\hline
\end{tabular}

\section{Motivations and Experiences: Recruitment and Retention}

Telephone interviews conducted after the completion of the volunteer efforts enabled the study authors to further examine motivations for participating in and persisting with the volunteer effort, as well as going on to participate in other, future forms of environmental stewardship.
Interview respondents were quick to identify the proximate drivers of their recruitment to TC2015: seeing an advertisement in subway or buses, reading about it on a listserv or email campaign, being invited through work or friends, or receiving a free concert ticket as an incentive. There were multiple pathways by which volunteers found themselves hearing about the program- 
from face-to-face, to traditional media, to digital media. In addition, because of the conversational context of semi-structured interviews, researchers were able to probe deeper to understand some of the underlying drivers of that engagement. For some, the opportunity came at the right place and the right time; they were at a life stage where they were looking for something to do (e.g., retired, in transition between jobs), and the events were held in locations that were accessible and convenient to join. These events were perceived as being primarily organized by NYC Parks, even when they were done in partnership with other stewardship groups (e.g., Brooklyn Botanic Garden, Gowanus Canal Conservancy).

Several important nuances about participant experience with TC2015 emerged through the interview process that shed light on why people came, as well as on why they continued to engage with the project, thereby providing insight not only into recruitment, but also into retention. Numerous participants expressed a desire to explore New York City neighborhoods by mapping and monitoring trees. While in many cases, volunteers first engaged locally, at sites convenient to their work or home. Oftentimes they went on to traverse the city, mapping blocks in unknown areas, and seeing their city in a new way. This theme of exploration was a predominant code across multiple interviews.

Overall, respondents described a high degree of satisfaction with the experience, for the most part finding the training and the technology easy and intuitive to learn. Specifically, some respondents were interested in learning about trees-particularly tree identification - and planned to use their tree identification cards in other future contexts. Others enjoyed the importance of the rewards that were offered for mapping more blocks. Participants appreciated the way in which the experience was fun and "gamified" by having various levels of achievement that could be reached, which stoked a healthy sense of competition.

Social dimensions of the experience varied with individual preference-some were highly interested in solo mapping, others came and worked in pairs, still others made friends with strangers who they met through the process and continued to work with over the course of the campaign, and others participated as part of large group training events. Numerous respondents reported highly salient citizen encounters during their work mapping on streets. The public was interested in understanding what was going on, and volunteers found themselves serving as ambassadors for the census, for NYC Parks, and for the urban forest more broadly. Given these experiences of collecting data and talking with interested publics, several respondents had questions about the management implications of this work. They were eager to understand how and why the data would be used to support successful management and maintenance of the urban forest.

Finally, when asked whether TC2015 triggered them to engage in future forms of civic or environmental action, many respondents focused instead on how they were already committed stewards. Indeed, it required a targeted question about future engagement to fully reveal the reciprocal relationship between past experiences as stewards, involvement in TC2015, and potential future activities going forward. Researchers found that many of the interviewees had past experience as volunteers or as stewards (even when they did not use that term) that influenced their interest in participating in TC2015. These past experiences ranged from being a member of a community garden, to being a citizen tree pruner, to participating in other NYC Parks stewardship events-including prior tree censuses. Many of the participants saw TC2015 as a new opportunity to express existing volunteerism, to participate, and to give back to the local environment and community. When seeking to understand volunteerism, it is important to consider not only recruitment pathways, but also program experience, and how the program fits into a person's broader trajectory, interests, and life stage. The assessment identified incentives as a key driver for a certain subset of volunteers (more likely to be non-white, Table 2); particularly notable was the provision of tickets to the Afropunk music festival for mapping trees in their neighborhood zone.

Linking these interviews to the TC2015 app database, researchers cross-tabulated coded themes of motivation with the number of city blocks inventoried by each interviewee (Table 6). Median blocks mapped was highest for interviewees mention- 
ing themes of Fun, Explore, and Past Experience, and lowest for interviewees mentioning Incentive, while the most common themes mentioned were Past Experience, Social / Meet People, and Values.

For interviewees, themes mentioned during time 1 (assessment) and time 2 (interview) were also examined. Table 7 identifies these combined results. For most interviewees, themes were consistent between both times. However, of particular note is a higher initial mention only (during the assessment) by some of the 40 interviewees for Values $(n=11)$, Educate $(n=9)$, Contribute $(\mathrm{n}=7)$, and Fun $(\mathrm{n}=7)$. At the same time, the deeper discussion of interviews and more time and experience with volunteering led to more elicitations of Past Experience ( $\mathrm{n}=18$ in interview only) and Social ( $\mathrm{n}=17$ in interview only). Researchers did not include the theme Explore in this table, as it only emerged during interviews.

\section{DISCUSSION}

From this study, one finds support that citizen science volunteers are motivated by a desire to improve the community, as well as individual benefits related to volunteerism. Motivations identified by TC2015 participants differed somewhat from motivations by tree planters under a previous long-term tree-planting program managed by NYC Parks, MillionTreesNYC (Fisher et al. 2015). Researchers find a similar focus on caring for the city and deepening social ties, yet for citizen scientists there is more of an overt desire for learning, education, and exploration. Given the rise of citizen-science opportunities, alongside an existing emphasis on community education by environmental volunteer groups (Measham and Barnett 2008), the potential exists to appeal to both community-focused and self-directed motivations. Future research could dig deeper into the learning aspect of these volunteers and also explore the links between the citizen-science motivations identified here with civic motivations identified by participants, to compare against this prior work with tree planters (Fisher et al. 2015).

Motivations identified by tree-monitoring volunteers are similar to motivations identified by environmental volunteers and citizen scientists in previous studies, with a few exceptions. Similar to Bruyere and Rappe (2007), volunteers identified wanting to contribute back to their community, spend time outdoors, holding environmental values, having fun, having previous experience, and being social/meet people. The desire to learn and self-educate was also a common theme, which aligns with motivations identified in other citizenscience research (e.g., Wright et al. 2015; Domroese and Johnson 2017). Distinct from previous research, a theme of external incentives identified the presence of a particular recruitment campaign involving free tickets to an Afropunk concert.

Table 6. Themes of TC2015 motivations from interviews $(n=40)$.

\begin{tabular}{|c|c|c|c|c|c|}
\hline Theme & $\begin{array}{l}\text { Proportion of } \\
\text { interviewees }\end{array}$ & $\begin{array}{l}\text { Average blocks } \\
\text { mapped }\end{array}$ & $\begin{array}{l}\text { Median blocks } \\
\text { mapped }\end{array}$ & $\begin{array}{l}\text { Minimum blocks } \\
\text { mapped }\end{array}$ & $\begin{array}{l}\text { Maximum blocks } \\
\text { mapped }\end{array}$ \\
\hline Past Experience & $55 \%$ & 147 & 36 & 1 & 1,109 \\
\hline Social / Meet People & $48 \%$ & 58 & 17 & 1 & 377 \\
\hline Values & $38 \%$ & 21 & 10 & 1 & 78 \\
\hline Contribute & $23 \%$ & 85 & 29 & 2 & 352 \\
\hline Explore & $23 \%$ & 256 & 77 & 4 & 1,109 \\
\hline Outdoors & $15 \%$ & 50 & 16 & 2 & 211 \\
\hline Educate / Learning & $10 \%$ & 36 & 19 & 2 & 102 \\
\hline Fun / Enjoyment & $5 \%$ & 69 & 69 & 17 & 120 \\
\hline Incentive & $5 \%$ & 15 & 15 & 4 & 25 \\
\hline
\end{tabular}

Table 7. Comparison between motivations mentioned in initial assessment and in interviews $(n=40)$.

\begin{tabular}{|c|c|c|c|c|c|c|c|c|}
\hline & Contribute & Educate & Fun & Incentive & Outdoors & Past experience & Social & Values \\
\hline Both & 26 & 28 & 30 & 37 & 33 & 20 & 21 & 24 \\
\hline Initial only & 7 & 9 & 7 & 2 & 1 & 0 & 0 & 11 \\
\hline Interview only & 6 & 2 & 2 & 0 & 5 & 18 & 17 & 5 \\
\hline Not identified & 1 & 1 & 1 & 1 & 1 & 2 & 2 & 0 \\
\hline Number of interviewees & 40 & 40 & 40 & 40 & 40 & 40 & 40 & 40 \\
\hline
\end{tabular}


Researchers found initial motivations varied by demographics, through integrating emergent motivation themes from open-ended questions with quantitative demographics data. Volunteer turnout was predominantly composed of welleducated, middle-aged, white participants, typical of environmental and citizen-science volunteers. Underrepresented were NYC residents of color and individuals without college degrees. Men were also underrepresented, although the survey sample may not be representative of gender (see Response Bias Checks). Demographics correlated with different motivations included race, income, political views, and proportion of life spent in New York City, suggesting opportunities for targeting recruitment efforts to better reach underrepresented populations. Identifying differences in motivations by demographic characteristics highlights an opportunity for diversifying and increasing turnout through altering recruitment strategies, as motivations can serve as a way to build a constituency of volunteers (Gobster and Hull 2000). For example, use of Afropunk concert tickets as an incentive (Incentive theme) was a motivating factor mentioned more often by non-white respondents than by other populations taking the assessment. Relative newcomers to New York City were more motivated by making a contribution (Contribute theme) than long-term residents. Newcomers may be seeking to enhance their connection with the city and its inhabitants, whereas long-term residents already have such connections in place. Long-term residents were motivated by having past experience with monitoring trees in New York City (Past Experience theme). Formal education level and age alone did not appear to be a factor in differing motivations mentioned, an interesting result given how $86.8 \%$ of assessment respondents had at least a bachelor's degree and the mean age of assessment respondents was 44 . Overall, the logistic regression models were well-specified for some motivation themes, but could not be well-fit for others (e.g., Outdoors and Social), suggesting some themes may be universal across demographic groups.

The assessment was administered immediately after an individual's involvement in training and one mapping event. Interviews after completion of the TC2015 census, more than one year later, identified some shifts in responses between when volunteers first began tree-monitoring efforts (assessment) and after the program had concluded (interviews). These shifts may be due to more experience with the program or differences in detail between the assessment and interviews. In comparing themes mentioned over time, researchers did observe some trends in Table 7, whereby some themes were mentioned more initially (Values, Contribute, Educate, Fun) and others emerged more in interviews (Past Experience, Social). This may be due in part to a bias in who agreed to follow-up interviews. Also, a new motivation emerged from the interviews: Explore, perhaps due to more time volunteering with TC2015 or because of the more in-depth nature of interviews. Exploration was a large part of the volunteer experience, whether it was exploring neighborhoods nearby or across the city from where individuals lived.

The theme Explore was also related to higher levels of participation by the interviewee. With this and other motivations, the amount of effort a volunteer contributed to TC2015 appeared to vary by the factors motivating the individual. Incentive as a motivation fell on the other end of the spectrum: it brought individuals out, but they did not sustain participation at high levels, when compared to other motivating factors. For TC2015, incentives were not tied to continued participation; this finding of lower participation by incentivemotivated individuals matches with current research on incentives and performance (e.g., Cerasoli et al. 2014). However, high levels of participation are not possible for all people, due to barriers like time and family needs. From a program perspective, a little participation by many can also be a desirable goal. Participation now can also lead to participation in other volunteer efforts later. As noted earlier, previous studies have shown stewardship volunteering to be an on-ramp for future volunteering and civic participation (Fisher et al.2015); through interviews, researchers see this result mirrored here with citizen-science volunteers.

To advance understanding citizen-science participation in cities, more work is needed on barriers presented to non-participants. Interviewing younger and underrepresented adults to examine barriers to participation in citizen science, Merenlender et al. (2016) found the primary barrier was not enough time, because of work and a focus on 
career advancement. Researchers of the current study found corresponding results from participants; during interviews, life course or having the time and ability to volunteer were commonly mentioned as factors enabling involvement. Past experience was also intertwined with people's careers, a motivation identified in the VFI (Clary and Snyder 1999). Further work could also examine the relationship between citizen science volunteer work and paid work, as volunteering can also contribute to job skills beneficial to the volunteer. The current study also included some limitations. The assessment underrepresented men and younger individuals among the responses, relative to the general New York City population. Also, the anonymous assessment benefitted respondents, but did not enable researchers to link assessment responses to mapped behaviors.

The study identified motivations for why trees count to volunteers in a city-led tree-monitoring effort. Through assessment and follow-up interviews, researchers found evidence of learning and discovery by volunteers, along with other personal or self-directed benefits. Researchers also identified more community-focused motivations of caring for a place and social connections, which have implications for managing social-ecological systems like cities. Knowing motivations to participate vary by demographics can inform volunteer program managers' recruitment for future tree-monitoring efforts. At the same time, recruitment alone is not a measure of success. It is important that volunteers are inspired to conduct the work in a responsible and timely matter, with the opportunity to deepen their knowledge to other or similar opportunities. In future volunteer efforts in New York City and elsewhere, motivations linked to higher numbers of blocks mapped, like Explore, Contribute, Social, and Outdoors could be emphasized in tree-monitoring recruitment materials. Incentives tied to outcomes (e.g., blocks mapped) could assist with recruiting and also retaining volunteers. Considering the suite of volunteer motivations, experiences, and outcomes can affect program participation turnout, effort, and retention.

Acknowledgments. The TreesCount! 2015 volunteer assessment was developed by a partnership between the City of New York Department of Parks and Recreation and the U.S. Forest Service. Particular thanks go to Fiona Watt, Crystal Crown, Danielle Gift, and Charles Cochrane at NYC Parks, as well as Katerli Bounds (formerly with NYC Parks). Thank you to Nancy Sonti and Crystal Crown for providing reviews of earlier drafts of this manuscript.
Supplemental Content. The Tree Census Volunteer Assessment (cited herein as SM1) and the Drivers, Outcomes, and Impacts of Volunteer Tree Monitoring Interview Protocol (SM2) are available for browsing on the website of the publisher, International Society of Arboriculture (www.isa-arbor.com). These materials are also available as an electronic file (.pdf) upon individual request (editor@isa-arbor.com).

\section{LITERATURE CITED}

Asah, S.T., and D.J. Blahna. 2012. Motivational functionalism and urban conservation stewardship: Implications for volunteer involvement. Conservation Letters 5(6):470-477.

Asah, S.T., and D.J. Blahna. 2013. Practical implications of understanding the influence of motivations on commitment to voluntary urban conservation stewardship. Conservation Biology 27(4):866-875.

Austin, M.E. 2002. Partnership opportunities in neighborhood tree planting initiatives: Building form local knowledge. Journal of Arboriculture 28(4):178-186.

Bell, S., M. Marzano, J. Cent, H. Kobierska, D. Podjed, D. Vandzinskaite, and H. Reinert, et al. 2008. What counts? Volunteers and their organizations in the recording and monitoring of biodiversity. Biodiversity and Conservation 17(14):3443-3454.

Boyle, M.P., and J.K. Sawyer. 2010. Defining volunteering for community campaigns: An exploration of race, self perceptions, and campaign practices. Journal of Community Practice 18(1):40-57.

Bramston, P., G. Pretty, and C. Zammit. 2011. Assessing environmental stewardship motivation. Environment and Behavior 43:776-788.

Bruyere, B., and S. Rappe. 2007. Identifying the motivations of environmental volunteers. Journal of Environmental Planning and Management 50(4):503-516.

Caldwell, L.L., and K.L. Andereck. 1994. Motives for initiating and continuing membership in a recreation-related voluntary association. Leisure Sciences 16(1):33-44.

Cerasoli, C.P., J.M. Nicklin, and M.T. Ford. 2014. Intrinsic motivation and extrinsic incentives jointly predict performance: A 40year meta-analysis. Psychological Bulletin 140(4):980.

Charmaz, K. 2001. Grounded theory. In: R.M. Emerson (Ed.). Contemporary Field Research: Perspectives and Formulations. Waveland Press, Long Grove, Illinois, U.S. 443 pp.

Clary, E.G., and M. Snyder. 1999. The motivations to volunteer: Theoretical and practical considerations. Current Directions in Psychological Science 8(5):156-159.

Clary, E.G., M. Snyder, and A.A. Stukas. 1996. Volunteers' motivations: Findings from a national survey. Nonprofit and Voluntary Sector Quarterly 25(4):485-505.

Clary, E.G., M. Snyder, R.D. Ridge, A.A. Stukas, J. Copeland, J. Haugen, and P.K. Miene. 1998. Understanding and assessing the motivations of volunteers: A functional approach. Journal of Personality \& Social Psychology 74:1516-1530.

Deci, E.L., and R.M. Ryan. 1985. The general causality orientations scale: Self-determination in personality. Journal of Research in Personality 19(2):109-134. 
Domroese, M.C., and E.A. Johnson. 2017. Why watch bees? Motivations of citizen science volunteers in the Great Pollinator Project. Biological Conservation 208:40-47.

Finkelstein, M.A. 2008. Volunteer satisfaction and volunteer action: A functional approach. Social Behavior and Personality 36(1):9-18.

Fisher, D.R., E.S. Svendsen, and J. Connolly. 2015. Urban Environmental Stewardship and Civic Engagement: How Planting Trees Strengthens the Roots of Democracy. Routledge Press, New York, New York, U.S. 132 pp.

Fisher, D.R., L.K. Campbell, and E.S. Svendsen. 2012. The organizational structure of urban environmental stewardship. Environmental Politics 21(1):26-48.

Foster-Bey, J. 2008. Do Race, Ethnicity, Citizenship and SocioeconomicStatusDetermineCivic-Engagement?CIRCLEWorking Paper\# 62. Center for Information and Research on Civic Learning and Engagement (CIRCLE). College Park, Maryland, U.S.

Geoghegan, H., A. Dyke, R. Pateman, S. West, and G. Everett. 2016. Understanding Motivations for Citizen Science. Final Report on behalf of the UK Environmental Observation Framework (May), 124. <www.ukeof.org.uk/resources/citizen-science-resources/MotivationsforCSREPORTFINALMay2016.pdf>

Gobster, P.H., and B. Hull (Eds.). 2000. Restoring Nature: Perspectives from the Social Sciences and Humanities. Island Press, Washington, D.C., U.S. 269 pp.

Grese, R.E., R. Kaplan, R.L. Ryan, and J. Buxton. 2000. Psychological benefits of volunteering in stewardship programs. pp. 265-280. In: P.H. Gobster and R. Hull (Eds.). Restoring Nature: Perspectives from the Social Sciences and Humanities. Island Press, Washington, D.C., U.S. 269 pp.

Groves, R.M. 2006. Nonresponse rates and nonresponse bias in household surveys. Public Opinion Quarterly 70(5):646-75.

Jordan, R.C., H.L. Ballard, and T.B. Phillips. 2012. Key issues and new approaches for evaluating citizen-science learning outcomes. Frontiers in Ecology and the Environment. Frontiers in Ecology and the Environment 10(6):307-309.

Kofinas, G.P. 2009. Adaptive co-management in social-ecological governance. pp. 77-101. In: F.S. Chapin, G.P. Kofinas, and C. Folke (Eds.). Principles of Ecosystem Stewardship: ResilienceBased Natural Resource Management in a Changing World. Springer-Verlag, New York, New York, U.S. 401 pp.

Lepper, M.R., D. Greene, and R.E. Nisbett. 1973. Undermining children's intrinsic interest with extrinsic reward: A test of the "overjustification" hypothesis. Journal of Personality and Social Psychology 28(1):129.

Lofland, J., D.A. Snow, L. Anderson, and L.H. Lofland. 2005. Analyzing Social Settings: A Guide to Qualitative Observation and Analysis. Wadsworth Publishing Company, Belmont, California, U.S. 304 pp.

Lu, J.W., E.S. Svendsen, L.K. Campbell, J. Greenfeld, J. Braden, K.L. King, and N. Falxa-Raymond. 2010. Biological, social, and urban design factors affecting young street tree mortality in New York City. Cities and the Environment 3(1):1-15.

Measham, T.G., and G.B. Barnett. 2008. Environmental volunteering: Motivations, modes, and outcomes. Australian Geographer 39(4):537-552.

Merenlender, A.M., A.W. Crall, S. Drill, M. Prysby, and H. Ballard. 2016. Evaluating environmental education, citizen science, and stewardship through naturalist programs. Conservation Biology 30(6):1255-1265.
Miller-Rushing, A., R. Primack, and R. Bonne. 2012. The history of public participation in ecological research. Frontiers in Ecology and the Environment 10(6):285-290.

Moskell, C., S.B. Allred, and G. Ferenz. 2010. Examining motivations and recruitment strategies for urban forestry volunteers. Cities and the Environment 3(1):article 9.

Musick, M.A., and J. Wilson. 2007. Volunteers: A Social Profile. Indiana University Press, Indiana University-Bloomington. 680 pp.

Neuman, W.L. 2003. Social Research Methods: Qualitative and Quantitative Approaches, fifth edition. Allyn and Bacon, Boston, Massachusetts, U.S.

Promberger, M., and T.M. Marteau. 2013. When do financial incentives reduce intrinsic motivation? Comparing behaviors studied in psychological and economic literatures. Health Psychology 32(9):950-957.

QSR International Pty Ltd. 2015. NVivo qualitative data analysis software, Version 11.

R Core Team 2017. R: A language and environment for statistical computing. R Foundation for Statistical Computing, Vienna, Austria. <https://www.R-project.org>

Roman, L.A., E.G. McPherson, B.C. Scharenbroch, and J. Bartens. 2013. Identifying common practices and challenges for local urban tree monitoring programs across the United States. Arboriculture \& Urban Forestry 39(6):292-299.

Ryan, G.W., and H.R. Bernard. 2003. Techniques to identify themes. Field Methods 15(1):85-109.

Ryan, R.L., R. Kaplan, and R.E. Grese. 2001 Predicting volunteer commitment in environmental stewardship programs. Journal of Environmental Planning and Management 44(5):629-648.

Ryan, R.M., and E.L. Deci. 2000. Intrinsic and extrinsic motivations: Classic definitions and new directions. Contemporary Educational Psychology 25:54-67.

Still, D.T., and H.D. Gerhold. 1997. Motivations and task preferences of urban forestry volunteers. Journal of Arboriculture 23(1):116-129.

Strauss, A., and J. Corbin. 1990. Basics of Qualitative Research: Grounded Theory Procedures and Techniques. SAGE Publications, Newbury Park, California, U.S. 272 pp.

Svendsen, E.S., and L.K. Campbell. 2008. Urban ecological stewardship: Understanding the structure, function, and management. Cities and the Environment 1(1):1-32.

Taniguchi, H. 2012. The determinants of formal and informal volunteering: Evidence from the American time use survey. Voluntas: International Journal of Voluntary and Nonprofit Organizations 23(4):920-939.

Vogt, J.M., and B.C. Fischer. 2014. A protocol for citizen science monitoring of recently-planted urban trees a protocol for citizen science monitoring of recently-planted urban. Cities and the Environment 7(2):article 4.

Westphal, L.M. 1993. Why trees? Urban forestry volunteers values and motivations. pp. 19-23. In: P.H. Gobster (Ed.). Managing Urban and High-use Recreation Settings. USDA Forest Service General Technical Report NC-163. North Central Experiment Station, St. Paul.

Wilson, J. 2012. Volunteerism research. Nonprofit and Voluntary Sector Quarterly 41:176-212.

Wright, D.R., L.G. Underhill, M. Keene, and A.T. Knight. 2015. Understanding the motivations and satisfactions of volunteers to improve the effectiveness of citizen science programs. Society \& Natural Resources 28(9):1013-1029. 
Michelle L. Johnson (corresponding author)

USDA Forest Service, Northern Research Station

michelleljohnson@fs.fed.us

Lindsay K. Campbell

USDA Forest Service, Northern Research Station

lindsaycampbell@fs.fed.us

\section{Erika S. Svendsen \\ USDA Forest Service, Northern Research Station \\ esvenden@fs.fed.us}

\author{
Philip Silva \\ The Nature Conservancy \\ New York City, New York, U.S. \\ philip.silva@gmail.com
}

Résumé. Les programmes de service volontaire peuvent être mieux reconnus grâce à une meilleure compréhension des motivations et des expériences des gens engagées dans la science citoyenne. À ce jour, la recherche a évalué les motivations des scientifiques amateurs et des planteurs d'arbres bénévoles. La recherche a mis moins d’emphase sur les bénévoles en dépistage arboricole, une activité en croissance rapide à mesure que les villes impliquent le public dans la surveillance des forêts urbaines. Les chercheurs ont effectué une évaluation des bénévoles ( $\mathrm{n}=636$ répondants) $\mathrm{du}$ TreesCount ! lors du recensement 2015 des arbres d'alignement à la ville de New York, NY, États-Unis, pour comprendre les données démographiques, les motivations, les expériences et le niveau d'engagement civique des bénévoles. Des entrevues semi-structurées (n $=40$ ) ont également été menées avec un sous-ensemble des répondants du groupe initial afin d'approfondir la compréhension de ces facteurs. À l'instar des bénévoles planteurs d'arbres des études antérieures, les bénévoles avaient de fortes chances d'être très scolarisés, de sexe féminin, de race blanche et avec un niveau de revenu élevé. Les principales motivations pour la participation étaient les valeurs personnelles, la volonté de contribuer et un désir de savoir ou d'apprentissage. Les données démographiques furent mises en corrélation avec différentes motivations, suggérant des pistes d'opportunité pour cibler les efforts de recrutement afin de mieux atteindre les populations sous-représentées. Les chercheurs ont également constaté que les motivations variaient légèrement lors des entrevues effectuées après le recensement, identifiant alors un nouveau motif, soit l'exploration de la ville. Le dépistage des arbres d'alignement présente des opportunités dont celle de contribuer à sa propre communauté ou ville et d'apprendre sur les arbres et la nature en ville, suggérant que ces actes d'engagement peuvent à la fois renforcer les liens dans une perspective socioécologique et générer des bénéfices personnels. En même temps, la prise en considération des motivations des volontaires, de leurs expériences, et de leurs impacts lors de l'élaboration des programmes peut avoir une incidence positive sur le taux de participation, les efforts consentis et la fidélisation.

Zusammenfassung. Freiwilligenprogramme können von einem tieferen Verständnis der Motivation und Erfahrung der in Bürgerwissenschaften engagierten Menschen profitieren. Die Forschung hat bis heute die Motivation der Bürgerwissenschaftler und Freiwilligen Baumpflanzer untersucht. Weniger Arbeit fokussierte auf den Baumerhebungsfreiwilligen, einer Rolle, deren Teilnehmerzahl schnell wächst, weil mehr Städte die Öffentlichkeit in die Beobachtung der urbanen Forste involvieren. Die Forscher leiteten eine Untersuchung von Freiwilligen ( $n=636$ Teilnehmer) in dem TreesCount! 2015 Baumerfassungszensus in New York City, New
York, U.S, um die Demographie, Motivation, Erfahrung und Grade von bürgerlichem Engagement zu verstehen. Semi-strukturelle Interviews $(n=40)$ wurden mit einem Subset der ersten untersuchten Freiwilligen durchgeführt, um das Verständnis der Faktoren zu vertiefen. Wie die Baumpflanzungs-Freiwilligen in den früheren Studien, waren die Freiwilligen mehr höher gebildet, weiblich, weiß und mit höheren Einkommensverhältnissen. Die selbst definierten Topmotivationen für die Teilnahme schlossen persönliche Wertvorstellungen, Wunsch nach Beitrag leisten, und ein Wunsch nach Weiterbildung oder Lernen ein. Die Demographie in Korrelation mit den verschiedenen Motivationen, die Gelegenheiten für Zielsetzungen bei der Rekrutierung offeriert, um besser unterrepräsentierte Bevölkerungsteile zu erreichen. Die Forscher fanden auch heraus, dass sich die Motivationslage in den Interviews nach dem Zensus verändert hat, sie identifizierten auch ein neues Thema, um die Stadt zu erforschen. Die Überwachung von Straßenbäumen präsentiert Möglichkeiten zur Teilnahme an der eigenen Kommune oder Stadt, und etwas zu lernen über Bäume und urbane Natur, wobei hier deutlich wird, dass diese engagierten Aktivitäten sowohl die Verbindungen zu einem sozio-ökologischen System stärken wie auch persönliche Vorteile liefern. Zur gleichen Zeit können unter Berücksichtigung der Motivation der Freiwilligen die Erfahrungen und Ergebnisse beim Design der Programme positiv die Teilnahme, den Aufwand und die Aufrechterhaltung beeinflussen.

Resumen. Los programas de voluntariado pueden beneficiarse de una comprensión más profunda de las motivaciones y las experiencias de las personas involucradas en la ciencia cívica. La investigación hasta la fecha ha estudiado las motivaciones de científicos ciudadanos y voluntarios de plantación de árboles. Menos trabajo se ha centrado en los voluntarios de monitoreo de árboles, un rol que está aumentando rápidamente a medida que más ciudades involucran al público en el monitoreo del bosque urbano. Los investigadores llevaron a cabo una evaluación de voluntarios ( $n=636$ encuestados) de TreesCount! Censo de árbol 2015 en la ciudad de Nueva York, Nueva York, EE. UU., para comprender la composición demográfica, las motivaciones, las experiencias y los niveles de participación cívica de los voluntarios. También se realizaron entrevistas semi estructuradas $(n=40)$ en un subconjunto de los encuestados de evaluación inicial, para profundizar la comprensión de estos factores. Al igual que los voluntarios que plantaron árboles en estudios previos, los voluntarios tenían más probabilidades de ser altamente educados, mujeres, blancos y con altos niveles de ingresos. Las principales motivaciones auto identificadas para la participación incluyen valores personales, querer contribuir y un deseo de educación o aprendizaje. La demografía se correlacionó con diferentes motivaciones, sugiriendo oportunidades para focalizar los esfuerzos de reclutamiento para llegar mejor a las poblaciones sub representadas. Los investigadores también encontraron que las motivaciones cambiaron ligeramente en las entrevistas posteriores al censo, y también identificaron un nuevo tema para explorar la ciudad. El monitoreo del árbol de la ciudad presenta oportunidades para contribuir con su comunidad o ciudad, y para aprender sobre los árboles y la naturaleza urbana, sugiriendo que estos actos de compromiso pueden fortalecer las conexiones con los sistemas socio-ecológicos y proporcionar beneficios personales. Al mismo tiempo, considerar las motivaciones, experiencias y resultados de los voluntarios al diseñar programas puede afectar positivamente la participación, esfuerzo y retención. 